\title{
ISLAMIC BANKING AND SOCIAL RESPONSIBILITY: STUDI KOMPARASI INDONESIA DAN MALAYSIA DENGAN PENDEKATAN ISLAMIC SOCIAL RESPORTING INDEKS DAN GLOBAL REPORTING INITIATIVE INDEKS
}

\author{
NISPA SARI \\ Institut Parahikmah Indonesia Gowa, Indonesia \\ nispa_sari@gmail.com
}

\begin{abstract}
This study aimed to compare the social performance between Islamic banking in Indonesia and Malaysia were measured by using a model of Islamic Social Reporting Index (ISR) and the Global Reporting Initiative Index (GRI). The objects of this study were drawn from four Islamic banks in Indonesia and three Islamic banks in Malaysia that meet certain criteria, namely; Islamic banking report annual report for 2010 and report the social responsibility disclosure. This study was used content analysis approach. The results showed that the overall average social performance of Islamic banking in Malaysia higher than social performance of Islamic banking in Indonesia. However, when tested statistically, the difference did not show significant value. Moreover, there are no Islamic banking in Indonesia and Malaysia reached a perfect level of social performance (100\%) of the ISR and the GRI index.
\end{abstract}

Keywords: Islamic Social Reporting Indeks, Global Reporting Initiative Index, Social Performance, Islamic Banking

\section{Pendahuluan}

Salah satu fungsi bank syariah sebagai jasa sosial mengharuskan bank syariah dapat memberikan manfaat kepada masyarakat dan lingkungan sekitarnya. Fungsi ini sering kali dikaitkan dengan tanggung jawab sosoial perusahaan (CSR) karena selain berorientasi untuk meningkatkan profit, bank syariah juga harus menjaga kesinambungan dalam hal ekonomi, lingkungan dan norma sosial serta dapat memenuhi harapan dari para stakeholders dan shareholders. Namun kenyataanya selama ini evaluasi terhadap kinerja bank lebih berfokus pada kinerja bisnis/ finansial semata cukup banyak penelitian yang menilai kinerja bank syariah yang dikenal dengan kesehatan bank syariah sementara kinerja sosial bank syariah sering terlupakan.

Beberapa ahli mengatakan bahwa sedikitnya ada empat model atau pola penerapan CSR yang biasanya diterapkan oleh perusahaan di Indonesia, yaitu: (1) 
keterlibatan langsung, (2) melalui yayasan atau organisasi sosial perusahaan, (3) bermitra dengan pihak lain dan (4) bergabung dalam suatu konsorsium.

Hingga saat ini belum ada definisi tetap atas tanggung jawab sosial, masing-masing pihak memiliki definisi dan interpretasi yang beragam mengenai CSR. Secara umum CSR dapat didefinisikan sebagai tanggung jawab yang dilakukan oleh perusahaan kepada para pemangku kepentingan untuk berlaku etis dan memenuhi seluruh aspek ekonomi, social dan lingkungan dengan baik demi pembangunan yang berkelanjutan (Wibisono 2007). ${ }^{1}$

Pengukuran kinerja sosial dibanyak perbankan syariah masih mengacu kepada Global Reporting Initiative Index (Indeks GRI), terkait dengan adanya kebutuhan mengenai pengungkapan kinerja sosial di perbankan syariah, saat ini marak diperbincangkan mengenai Islamic Social Reporting Index (Indeks ISR). Indeks ISR merupakan tolok ukur pelaksanakaan kinerja perbankan syariah yang berisi kompilasi item-item standar CSR yang ditetapkan oleh AAOIFI (Accounting and Auditing Organization for Islamic Financial Institutions). Penelitian menganai Indeks CSR dengan indeks ISR diindustri perbankan syariah umumnya dilakukan di negara-negara lain, mengingat industri perbankan syariah di Indonesia dan Malaysia saat ini sedang tumbuh dengan cukup pesat, ditambah dengan isu pengukuran kinerja sosial yang makin marak, maka penelitian ini mencoba untuk menelaah bagaimana kinerja sosial bank syariah ditinjau dengan pendekatan Islamic Social Reporting Index (Indeks ISR) dan Global Reporting Initiative Index (Indeks GRI) yang dilakukan oleh industri perbankan syariah di Indonesia dan Malaysia.

\section{Review Literature}

Sistem perbankan Islam, seperti halnya aspek-aspek lain dari pandangan hidup Islam, merupakan sarana pendukung untuk mewujudkan tujuan dari sistem sosial dan ekonomi Islam. Beberapa tujuan dan fungsi penting yang diharapkan dari sistem perbankan Islam, menurut Chapra, antara lain: (a) Kemakmuran ekonomi yang meluas dengan tingkat kerja penuh dan tingkat pertumbuhan ekonomi yang optimum; (b) Keadilan sosial ekonomi dan distribusi pendapatan serta kekayaan yang merata; (c) Stabilitas nilai uang untuk memungkinkan alat tukar tersebut menjadi suatu unit perhitungan yang terpercaya, standar pembayaran yang adil dan nilai simpan yang stabil; (d) Mobilisasi dan investasi tabungan bagi pembangunan ekonomi dengan cara-cara tertentu yang menjamin bahwa pihak-pihak yang berkepentingan mendapatkan bagian pengembalian yang adil; dan (e) Pelayanan yang efektif atas semua jasa-jasa yang

\footnotetext{
${ }^{1}$ Hafiez Sofyani, dkk., "Islamic social reporting index sebagai model pengukuran kinerja sosial perbankan syariah (studi komparasi indonesia dan malaysia)", Jurnal Dinamika Akuntansi Vol. 4, No. 1, 2012) h. 37.
} 
biasanya diharapkan dari sistem perbankan. Dalam pandangan Chapra, jelas sekali bahwa selain memberikan jasa keuangan yang halal bagi komunitas muslim sebagai tujuan khusus, sistem keuangan dan perbankan Islam diharapkan juga memberikan kontribusi bagi tercapainya tujuan sosiol-ekonomi Islam. ${ }^{2}$

ISR pertama kali digagas oleh Ross Haniffa pada tahun 2002 dalam tulisannya yang berjudul "Social Reporting Disclosure: An Islamic Perspective". ISR lebih lanjut dikembangkan secara lebih ekstensif oleh Rohana Othman, Azlan Md Thani, dan Erlane K Ghani pada tahun 2009 di Malaysia dan saat ini ISR masih terus dikembangkan oleh peneliti-peneliti selanjutnya. Menurut Haniffa (2002) terdapat banyak keterbatasan dalam pelaporan social konvensional, sehingga ia mengemukakan kerangka konseptual ISR yang berdasarkan ketentuan syariah. ISR tidak hanya membantu pengambilan keputusan bagi pihak muslim melainkan juga untuk membantu perusahaan dalam melakukan pemenuhan kewajiban terhadap Allah dan masyarakat. ${ }^{3}$

Penerapan GRI pada industri perbankan telah dilakukan oleh penelitian sebelumnya. Fitria dan Hartanti (2010), melakukan penelitian terhadap 3 bank konvensional dan 3 bank syariah. Hasil penelitian menunjukkan bahwa pengungkapan CSR bank konvensional lebih baik dibandingkan bank syariah. Berdasarkan indeks GRI, nilai tertinggi sebesar $46 \%$ dan berdasarkan indek ISR nilai tertinggi sebesar 58\%. Pengukuran yang digunakan adalah indeks GRI (72 item) dan Islamic Social Reporting (ISR) dikembangkan berdasarkan AAOIFI. Trisnawati (2011) melakukan analisis pengungkapan CSR pada bank konvensional dan syariah di Indonesia menggunakan indeks GRI 78 item. Hasil penelitiannya konsisten dengan temuan Fitria dan Hartanti (2010) bahwa pengungkapan CSR bank konvensional lebih baik dibandingkan bank syariah yaitu 52\% dan 37\%. Selanjutnya Trisnawati, et.al (2012) melakukan analisis pengungkapan CSR pada bank syariah di Indonesia dengan indeks ISR. Hasil penelitian menunjukkan bahwa pengungkapan dengan ISR sebesar $50.68 \%{ }^{4}$

\section{Rational}

Sejauh ini pengukuran CSR disclosure pada perbankan syariah masih mengacu kepada Global Reporting Initiative Index (Indeks GRI) (Haniffa 2002). Padahal, terkait dengan adanya kebutuhan mengenai pengungkapan kinerja sosial di perbankan syariah, saat ini marak diperbincangkan mengenai Islamic Social Reporting Index (ISR). Indeks ISR merupakan tolok ukur pelaksanaan kinerja

\footnotetext{
${ }^{2}$ Luhur Prasetiyo, "Corporate Social Responsibility (CSP) Bank Syariah Di Indonesia", Jurnal vol 8 no. 1 tahun 2014, h. 149.

${ }^{3}$ Gustani. "Model Pelaporan Kinerja Sosial Perbankan Syariah: Implementasi Islamic Social ReportIng Index (Indek ISR) Di Indonesia", Jurnal Akuntansi dan Keuangan Islam 1, No. 2, 2013, h. 38.

4 Rina Trisnawati, dkk. "Pengungkapan Islamic Social Reporting pada Bank Syariah di Indonesia". Proceeding Seminar Nasional dan Call For Paper Sancall, 2013. h. 104.
} 
sosial perbankan syariah yang berisi kompilasi item-item standar CSR yang ditetapkan oleh AAOIFI (Accounting and Auditing Organization for Islamic Financial Institutions) yang kemudian dikembangkan lebih lanjut oleh para peneliti mengenai item-item CSR yang seharusnya diungkapkan oleh suatu entitas Islam Othman et al. 2009). ${ }^{5}$

Berdasarkan pembahasan yang dipaparkan, maka diperlukan sebuah kajian tentang bagaimana kinerja sosial perbankan syariah di Indonesia dan Malaysia dilaksanakan, ditinjau dengan menggunakan model Islamic Social Reporting Index, serta untuk mengkaji perbedaan pada kinerja sosial yang dilaksanakan oleh industri perbankan syariah di Indonesia dan Malaysia ditinjau dengan menggunakan model Islamic Social Reporting Index.

\section{Method and Desain}

Jenis penelitian ini adalah studi komparatif, dimana penelitian akan difokuskan pada analisis dalam rangka membandingkan suatu objek penelitian antar subjek dan model pengukuran yang berbeda dalam kurun waktu yang sama. Objek penelitian diambil dari empat bank syariah di Indonesia dan Malaysia dengan kriteria melaporkan laporan tahunan (Annual Report) periode 2016 dan memuat semua kategori dari Indeks ISR \& Indeks GRI dalam pelaporan kinerja sosialnya, yakni Bank Muamalat Indonesia, Bank Syariah Mandiri, Bank Rakyat Indonesia Syariah, Bank Negara Indonesia Syariah dan Bank Islam Malaysia Berhad, CIMB Islamic Bank, May Bank Islamic Berhad, dan RHB Islamic Bank.

Penelitian ini menggunakan teknik analisis isi (Conent analysis) dengan pendekatan scoring atau pembobotan dalam rangka menilai kinerja sosial yang dilaksanakan dan dilaporkan oleh objek penelitian. Setiap pelaksanaan dan pelaporan aktivitas sosial oleh objek penelitian akan diberi nilai (skor) " 1 " dan jika dan nilai " 0 " jika tidak melaporkannya. ${ }^{6}$

Konstruk dari Indeks ISR yaitu: Investasi dan Keuangan (Finance And Investment Theme), Produk dan Jasa (Products And Services Theme), Tenaga Kerja (Employees Theme), Sosial (Society Theme), Lingkungan (Environment), dan Tata Kelola Organisasi (Corporate Governance Theme). Sedangkan konstruk dari Indeks GRI yaitu: Profil dan Strategi Organisasi, Lingkup Ekonomi, Lingkup Lingkungan, dan Lingkup Sosial. Apabila seluruh item dari masing-masing indeks ISR dan GRI dilaksanakan dan dilaporkan oleh bank syariah selaku objek penelitian, maka skor maksimal (sama dengan 100\%) yang dapat dicapai sebesar 43 untuk Indeks ISR dan 144 untuk Indeks GRI. Selanjutnya, hasil

\footnotetext{
${ }^{5}$ Hafiez Sofyani, Ihyaul Ulum, Daniel Syam, Sri Wahjuni L. Islamic social reporting index sebagai model pengukuran kinerja sosial perbankan syariah (studi komparasi indonesia dan malaysia): Jurnal Dinamika Akuntansi Vol. 4, No. 1, 2012) h. 37

${ }^{6}$ Hafiez Sofyani. Islamic Social Reporting Index Sebagai Model Pengukuran Kinerja Sosial Perbankan Syariah (Studi Komparasi Indonesia dan Malaysia). Dipresentasikan pada Forum Dosen Ekonomi Islam Universitas Lambung Mangkurat Banjarmasin, 2011. h 3-4
} 
skoring akan diuji dengan $t$-test untuk mengetahui apakah perbedaan skor kinerja sosial di perbankan syariah Indonesia dan Malaysia memang berbeda secara statistik atau kah tidak.

\section{Perbandingan Tingkat Kinerja Sosial Perbankan Syariah Indonesia dan Malaysia Berdasarkan Indeks ISR}

Diketahui bahwa kinerja sosial perbankan syariah dilihat menggunakan Indeks ISR tertinggi ditempati Bank Islam Malaysia yaitu sebesar 79,76\%. Adapun untuk tingkat kinerja sosial terendah ditempati oleh Bank Negara Indonesia Syariah. Sedangkan dari rata-rata tiap negara, perbankan syariah Malaysia memiliki tingkat kinerja sosial yang lebih tinggi jika dibandingkan dengan perbankan syariah Indonesia.

Secara statistik, berdasarkan hasil uji beda rata-rata (Independent sample test), diperoleh nilai $\mathrm{F}$ hitung sebesar 0,00 dengan probabilitas (sig) 0,998. Karena probabilitas dari $\mathrm{F}$ hitung lebih besar dari 0,05, maka dapat disimpulkan tingkat kinerja sosial dari perbankan syariah di Indonesia dan Malaysia memiliki variance yang sama. Dengan demikian, analisis uji beda (t-test) harus menggunakan asumsi equal variance assumed. Dari uotput SPSS, dapat dilihat dari nilai t pada equal variance assumed adalah sebesar 0,617 dengan probabilitas ( $P$-value) sebesar 0,542 (lebih dari 0,05). dengan demikian dapat disimpulkan bahwa antara kinerja sosial perbankan syariah di Indonesia dan Malaysia yang diukur dengan indeks ISR, secara statistik tidak terdapat perbedaan signifikan.

\section{Perbandingan Tingkat Kinerja Sosial Perbankan Syariah Indonesia dan Malysia Berdasarkan Indeks GRI}

Kinerja sosial bank syariah tertinggi ditempati oleh Bank Islam Malaysia Berhad dengan tingkat mencapai $47,49 \%$. Sedangkan tingkat kinerja sosial terendah ditempati oleh Bank Negara Indonesia Syariah dengan capaian 39,71\%. Sedangkan secara rata-rata keseluruhan, tingkat kinerja sosial perbankan syariah di Malaysia lebih tinggi dibandingkan dengan perbankan syariah di Indonesia jika diukur dengan indeks GRI.

Secara statistik, berdasrkan hasil uji beda rata-rata (Independent sample test), diperoleh nilai $\mathrm{F}$ hitung sebesar 1,359 dengan probabilitas (sig) 2,47. Karena probabilitas dari $\mathrm{F}$ hitung lebih besar dari 0,05, maka dapat disimpulkan tingkat kinerja sosial dari perbankan syariah di Indonesia dan Malaysia memiliki variance yang sama. Dengan demikian, analisis uji beda (t-test) harus menggunakan asumsi equal variance assumed. Dari uotput SPSS, dapat dilihat dari nilai t pada equal variance assumed adalah sebesar 1,00 dengan probabilitas (P-value) sebesar 0,319 (lebih dari 0,05). Dengan demikian dapat disimpulkan bahwa antara kinerja sosial perbankan syariah di Indonesia 
dan Malaysia yang diukur dengan indeks GRI, secara statistik juga tidak terdapat perbedaan signifikan.

\section{Pembahasan}

Dalam menjalankan aktivitas sosialnya, hampir semua bank syariah di Indoensia mengalokasikannya dari dana kebajikan (Qardhul hasan) yang diperoleh dari aktivitas non halal bank dan dari denda atas keterlambatan pengembalian kewajiban oleh nasabah yang tidak boleh dimasukkan kedalam pendapatan operasi bank. Selain dana kebajikan, semua bank syariah juga mengalokasikan dana untuk aktivitas sosialnya dari zakat perusahaan, zakat karyawan, serta zakat dan infak dari nasabah bank. Mengenai berapa besar jumlah yang dianggarkan untuk dana sosial ini, tidak satu pun bank syariah yang secara khusus menentukan besarnya persentase untuk dana sosial dari laba yang didapat oleh bank. Karena apabila terjadi suatu peristiwa atau bencana alam yang membutuhkan dana cukup besar, bank syariah juga mengumpulkan dana dengan membuka pos bantuan dan menjadi bank penyalur dana sosial dari masyarakat atau institusi lainnya.

Secara keseluruhan kinerja sosial perbankan syariah di Indonesia dan Malaysia, baik diukur dengan indeks ISR maupun indeks GRI, semua bank syariah tidak satupun yang melaksanakan aktivitas sosialnya secara sempurna $(100 \%)$. Hal ini disebabkan oleh dua faktor, yakni; pertama dikarenakan bank syariah memang tidak melaksanakan aktivitas sosial yang sebenarnya mereka mampu untuk melaksanakannya seperti melaporkan aktivitas gharar dan nasabahnasabah yang bermasalah dengan bank syariah(untuk pendekatan indeks ISR). Dalam kasus ini, hampir semua bank syariah di Indonesia tidak melaporkannya. Kedua, dipengaruhi oleh adanya item-item pengukuran dengan model Indeks ISR dan model Indeks GRI yang memang bank tidak melaksanakan aktivitas itu, seperti bantuan untuk aktivitas politik, audit lingkungan terkait limbah, memproduksi komoditas alami (Green Product), indikator kinerja lingkungan, aspek energi dan air, serta aspek keragaman hayati. Keberadaan item-item tersebut dikarenakan Indeks ISR dan Indeks GRI tidak hanya diperuntukkan bagi perbankan syariah, tetapi juga bagi perusahaan baik pertambangan, dagang, jasa, maupun manufaktur.

Perbankan syariah berhubungan dengan industri lain seperti perumahan dan industri manufaktur dalam hal kerjasama pembiayaan usaha, sehingga perbankan syariah secara tidak langsung juga berkaitan dengan aspek-aspek yang disebutkan di atas. Oleh karena itu, bank syariah bisa saja andil bagian dalam menjalankan aktivitas sosial dengan memberikan syarat tertentu kepada industri sebelum memberikan pembiayaan, misalnya perusahaan perumahan yang bekerja sama dengan bank syariah harus menjalankan aktivitas sosial seperti green product, pengelolaan air, dan aktivitas lainnya yang berkaitan dengan perbaikan 
lingkungan.Meski demikian, tingkat kinerja sosial perbankan syariah di dua negara relatif bagus karena sudah melebihi separuh (> 50\%) dari aktivitas yang seharusnya dilakukan.

Temuan yang menarik dari penelitian ini adalah, dari hasil scoring, perbandingan indeks ISR dan indeks GRI bahwa kinerja sosial perbankan syariah berdasarkan indeks ISR lebih tinggi dibandingkan indeks GRI. Hal ini berbeda dengan hasil penelitian yang dilakukan Fitria dan Hartatnti (2010) dimana data yang digunakan adalah laporan tahunan perbankan syariah tahun 2010. Penelitian Fitria dan Hartanti (2010) menemukan bahwa kinerja sosial perbankan syariah yang diukur dengan Indeks GRI lebih tinggi daripada Indeks ISR. Hal ini menunjukkan bahwa perbankan syariah, khususnya di Indonesia, mulai bergeser untuk menjalankan aktivitas sosial dari yang awalnya berdasarkan indeks GRI menuju indeks ISR yang notabene dirancang untuk unit bisnis syariah. Perkembangan positif ini seharusnya lebih ditingkatkan lagi karena sesuai dengan konsep governance management, industri bisnis harus berupaya untuk menyeimbangkan tujuan untuk keuntungan keuangan dan tujuan untuk kemaslahatan sosial.

\section{Simpulan}

Dalam penelitian ini, penulis mencoba untuk melihat kembali perbandingan tingkat kinerja sosial perbankan syariah di Indonesia dan Malaysia dengan empat bank. Dari hasil analisis, diperoleh beberapa simpulan.

Pertama, secara umum perbankan syariah di Malaysia memiliki tingkat kinerja sosial yang lebih tinggi dibandingkan perbankan syariah yang ada di Indonesia. Namun demikian, secara statistik tidak terdapat perbedaan signifikan antara perbankan syariah Indonesia dan Malaysia saat diuji dengan uji beda (uji-t), atau dengan kata lain tingkat kinerja sosial perbankan syariah di kedua negara tersebut relatif sama.

Kedua, dari semua bank syariah baik Indonesia maupun Malaysia, masih belum ada satupun yang mencapai angka penuh, yakni implementasi dan pengungkapan Indeks ISR dan Indeks GRI secara sempurna (100\%). Hal ini diarenakanuntuk sub-item Environmental Audit (Audit Lingkungan) dan Endangered Wildlife (Perlindungan terhadap Hutan Krisis) yang ada pada indeks ISR dan beberapa sub-item pada indeks GRI, tidak ada satu pun perbankan syariah melaksanakan aktivitas tersebut. Jika dilihat dari jenis industrinya, memang perbankan syariah tidak diwajibkan untuk melaksanakan dan melaporkan aktivitas pada sub-item Environmental Audit (Audit Lingkungan) dan Endangered Wildlife (Perlindungan terhadap Hutan Krisis).

Meski tidak mencapai tingkat kinerja sosial yang sempurna (100\%), akan tetapi tingkat kinerja sosial perbankan syariah di dua negara relatif bagus karena sudah melebihi separuh (>50\%) dari aktivitas yang seharusnya dilakukan. 
Simpulan terakhir yaitu berdasarkan temuan penelitian, dapat disimpulkan bahwa perbankan syariah, khususnya di Indonesia, memiliki intensi untuk mulai bergeser dalam cara menjalankan aktivitas sosial dari yang awalnya berdasarkan indeks GRI menuju indeks ISR yang notabene dirancang untuk unit bisnis syariah.

Saran penulis terkait penelitian dengan isu yang sama adalah pertama, jumlah objek perbankan yang diteliti dalam penelitian ini relatif sedikit, yakni hanya empat bank umum syariah di Indonesia dan empat bank syariah di Malaysia sehingga terdapat keterbatasan dalam generalisasi hasil penelitian. Meski demikian, hal tersebut bukan kelemahan yang disebabkan kemalasan peneliti, melainkan karena memang jumlah objek penelitian yang sesuai dengan kriteria hanya berjumlah tiga objek penelitian.

Adapun keterbatasn kedua, penelitian ini dilakukan hanya pada satu waktu tertentu saja (cross sectional) yaitu tahun 2016 sehingga tidak mampu menangkap perubahan-perubahan terutama yang berpengaruh pada evaluasi pengungkapan di tahun sebelum dan tahun berikutnya. Ketiga, penggunaan Indeks ISR dan Indeks GRI yang item-itemnya merupakan hasil pengembangan penulis memungkinkan adanya indikator yang kurang dikembangkan secara komprehensif. Oleh karena itu, penelitian selanjutnya harus dapat mengembangkan item- item secara lebih detail dan komprehensif.

\section{Significance and Conclusion}

Penelitian ini dapat memberikan signifikansi bagi pengembangan ilmu pengetahuan dalam spektrum integrasi keilmuan pada perguruan tinggi baik Institut parahikma Indonesia khususnya dan perguruan tinggi secara umumnya. Dengan melihat perkembangan perbankan syariah pada Negara-negara islam didunia termasuk Indonesia mendorong kesadaran masyarakat akan pentingnya implementasi, pelaporan dan pengungkapan CSR yang sesuai dengan prinsip syariah, maka dibutuhkan suatu standar pengungkapan yang dapat diterima secara umum dengan tetap berdasarkan prinsip-prinsip syariah. Penelitian ini dirancang untuk mengukur kinerja, pelaporan dan pengungkapan pada bank syariah Indonesia dan Malaysia dengan melakukan penyesuaian dan konvergensi terhadap indeks ISR dan GRI.

Mengenai praktek CSR dilembaga perbankan syariah haketkatnya medasarkan pada filosofi dasar Al Qura'an dan Sunnah. Sehingga ini menjadikan dasar bagi pelakunya dalam berinteraksi dalam lingkungan dan sesamanya. Mengingat dasar filosofi tersebut religius, maka diyakini bahwa hubungan yang ada lebih bersifat berkelanjutan dibandingkan pola CSR konvensional. Islamic social reporting indeks dan kinerja sosial perusahaan (CSR) menjadi suatu hal yang penting untuk mendukung praktik tanggungjawab sosial dan syariah di Indonesia. 


\section{Daftar Pustaka}

Gustani, (2013). Model Pelaporan Kinerja Sosial Perbankan Syariah: Implementasi Islamic Social ReportIng Index (Indek ISR) Di Indonesia. Jurnal Akuntansi dan Keuangan Islam 1, No. 2, 2013.

Prasetiyo Luhur, (2014). Corporate Social Responsibility (CSR) Bank Syariah Di Indonesia : Jurnal vol 8 no. 12014.

Risnawati Rina, dkk. (2013). Pengungkapan Islamic Social Reporting pada Bank Syariah di Indonesia : Proceeding Seminar Nasional dan Call For Paper Sancall.

Sofyani Hafiez, (2012). Islamic social reporting index sebagai model pengukuran kinerja sosial perbankan syariah (studi komparasi indonesia dan malaysia): Jurnal Dinamika Akuntansi Vol. 4, No. 1, 2012.

(2011). Islamic Social Reporting Index Sebagai Model Pengukuran Kinerja Sosial Perbankan Syariah (Studi Komparasi Indonesia dan Malaysia). Dipresentasikan pada Forum Dosen Ekonomi Islam Universitas Lambung Mangkurat Banjarmasin, 2011.

Uma Sekaran, (2007). Research Methods for Business. Edisi 4, Jakarta : Salemba Empat. 